of the island. A start has been made in raising the building fund, and Mr. Henry R. Davis, of Treborth, who acted as hon. treasurer of the Puffin Island station since 1892, has made a handsome contribution. It is hoped that his example will be largely followed.

With regard to maintenance, hopes are entertained that some money from Government sources will be available. A year ago the College approached the Board of Trade with a view of obtaining a grant to enable it to undertake systematic investigations in connection with fisheries, and recently the College put forward its claims for support before the Ichthyological Committee of the Board.

\section{FORESTR $Y$.}

THE opening paper in the Transactions of the Royal Scottish Arboricultural Society, I90I (vol. xvi. part iii.) is by Mr. J. S. Gamble, C.I.E., F.R.S., and gives a full account of the Forestry Exhibition in Paris in 1900, in the "Palais de Forêts, de la Chasse et des Cueillettes," the latter term practically meaning productions of various kinds, from baskets and fishingrods to sponges and Russian caviare. The chief exhibit by the French Government was a series of models, photographs, pamphlets, \&c., on the reclamation of mountain sides, including a large diorama representing a hill-side before-and several years after-reclamation. All these illustrate the magnificent work done by France in the last forty years, during which nearly 640 square miles of country have been reafforested at a cost of about two and a half million pounds. $\mathrm{Mr}$. Gamble refers to the necessity of such work being undertaken in the Himalayas, where landslips due to forest denudation have wrought wholesale destruction. $\mathrm{He}$ instances hill-slopes which he once knew as covered with fine forests, but which are now bare and scored with landslips, while their gentle streams have been converted into torrents. The "sufficient for the day" policy of Indian administrators constantly neglects the work of preserving mountain forests, which is done seriously and systematically and with the best results in France, Austria and Hungary. The possession of a world-wide empire should induce us also to undertake such an obvious duty. More has been done in India to fix shifting sands, chiefly by means of casuarina plantations along the Coromandel coast, here also following the great French work in Gascony, where 260 square miles have been reclaimed and planted with maritime pine. The Germans have also afforested nearly the whole North German coast with Pinus sylvestris.

A great feature of the International Sylvicultural Congress held at Paris during the progress of the Exhibition was M. Mélard's paper on the world's annual excess of imports over exports of timber, which he estimated at 3,437, I I 5 . in I 898 , the chief importing countries being Britain, showing an annual excess of imports lover exports of $20,523,758 l$, and Germany, 13,741,240l., and the chief exporting ones Austria-Hungary, having an excess of exports over imports of $7,94 \mathrm{I}, 422 l$., Sweden, $7,927,080 l$., Russia, 5,361, 285l, and Canada, 5,077,756l. Alluding to the enormous imports of timber into the British Isles, M. Mélard notes that we have annually to build houses, factories and workshops for an increased population of 300,000 , more than equal to that of Bordeaux, the third town in France. The large imports of timber into Germany, where 26 per cent. of the country is forest, much of which is scientifically managed, is a remarkable proof of the recent great economic development of that country.

The second paper in the Transactions is a reprint of Dr. Schlich's lecture at the Society of Arts, London, on February 27 , I90r, on the world's timber supply, which gives more recent figures than M. Mélard's. Dr. Schlich had broken ground on this subject in March, 1897, in a lecture at the Imperial Institute; in the present paper he gives very full statistics, and sums up with the statement that plenty of hardwood is still available, but that coniferous wood (soft-wood), which forms 85 per cent. of the total demand, can be continuously provided only by Sweden, Russia and Canada. Sweden, where the forests are well managed, may be able to increase its yield to $1,500,000$ tons, out of a total demand of about 9,000,000 tons of coniferous timber, but the Russian supply is precarious; the great stand-by for coniferous timber will be Canada, if the Dominion Government does not lose time in introducing a rational management of the Canadian forests.

No. I707, voL. 66$]$
There are two useful papers by Mr. R. C. Munro Ferguson, M.P., the first on the arboricultural adornment of towns, with a list, by Prof. Bayley Balfour, of the shrubs and trees flourishing in the Royal Botanic Garden, Edinburgh. It is not, says Prof. Balfour, the low temperature of Edinburgh that retards the growth of woody plants, but winds blowing during cold weather deprive the plants of their water, so that, given shelter, a large number of trees and shrubs may be grown. $\mathrm{Mr}$ Ferguson's second paper is entitled "Hints on the Training of Foresters." The advice given is excellent, and should be read by all young woodmen. Schools for woodmen might with advantage be established in the Crown woodlands adjoining the Forest of Dean and the New Forest, as well as near Edinburgh, but the great requisite for this country in forestry education is that it should be available at our universities, so that land owners, land agents and future colonial administrators may be taught the importance of forestry. At present it takes several years to teach a new colonial governor. not to devastate woodlands, and as soon as he has learned the lesson and prepared a useful forest scheme he has to go, and his successor frequently upsets all he has done.

Several useful papers follow by different authors, chiefly estate woodmen, and in one of these, by Mr. D. A. Glen, on "Forestry in Kent and Sussex," the following passage occurs :"In many of these woods, not only the dead leaves, but every bit of herbage and vegetable undergrowth is carefully raked together and carted away to make litter, which, after it has been well rotted in the cattle-sheds, is utilised as manure for the hop-fields." This practice is apparently also followed in Hampshire, and the future ruin of these impoverished woodlands is as certain as those treated similarly near Nuremberg, where the Scotch pine has become a dwarf tree rarely exceeding I 2 feet in height.

Paper No. 41 of the Transactions is an accomt of a deputation last October to the President of the Board of Agriculture. This has been followed by the appointment by Mr. Hanbury of a Departmental Committee, " to inquire into and report as to the present position and future prospects of forestry, and the planting and management of woodlands in the United Kingdom, and to consider whether any further measures might with advantage be taken, either by the provision of further educational facilities, or otherwise, for their promotion and en. couragement." Mr. Hanbury's committee is admirably selected, and the best results may be anticipated from its deliberations if only money is forthcoming to carry them out.

Colonel Bailey, R.E., the Instructor in Forestry at Edin. burgh, gives some "Notes on the Forests of Norway," chiefly compiled from an official publication, which will be very useful to the members of the Royal Scottish Arboricultural Society in their proposed excursion to Norway this year. Last year's excursion was to woodlands near Glasgow, an account of which and several useful notes and queries on forest questions close this volume. The Society is to be congratulated on the excellent work done under its auspices.

While the Royal Scottish Arboricultural Society has been in existence for forty-eight years and contains more than 900 members, the English sister society is twenty years old and contained 513 members when the last volume of its transactions was published.

These transactions, in the first place, deal with last year's excursion to some interesting woodlands within easy reach of Peterborough. Then follow the two prize essays, to each of which a silver medal was awarded, the former by Mr. J. Price, on forest roads, with diagrams, a most useful paper, and the latter by Mr. A. Deane, of the Warrington Museum, giving descrip. tions of the structure of British woods, with beautiful repro. ductions of photographs of transverse sections of each species. Other interesting papers follow: "Arboreal Tunnellers" (leopard moth, hornet clearwing, goat moth and wood wasp), by Mr. C. Morley; and on an oak canker due to a species of Stereum, which the author considers to be new, and proposes to call Stereum quercinum, by Mr. M. C. Potter, Professor of Botany at the College of Science, Newcastle.

Sir Hugh Beevor contributes the financial history of a fouracre mixed plantation, calculating the rate of interest at 4 per cent., which Sir J. Hooker considers forestry should pay before it will attract attention from investors. The financial history of this plantation is summarised in the following statement, which is of sufficient general interest for reproduction in the pages of NATURE. 
(I) INCOME.

Annual recurrent Income per acre:-

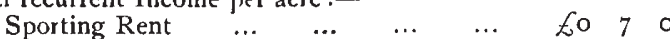

£o $7 \quad 7 \quad 0$

$(2)$

Feling Rl.ceipts-4 Acres. Total
Receipts Expenses Expenses Net Date. Age. Trees Felled. $\begin{gathered}\text { Receipts } \\ \text { including Expenses Expenses Net } \\ \text { underwood. Extraction. }\end{gathered}$

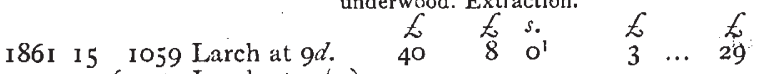

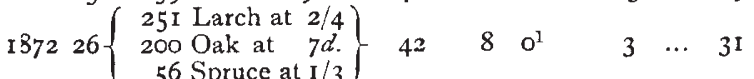
I880 $34\left\{\begin{array}{c}562 \text { Larch at } 6 / 8 \\ 174 \text { Oak at } 2 / 5 \\ 40 \text { Spruce at } 2 / 2\end{array}\right\} \quad 85\left\{\begin{array}{c}\text { Felling } \\ 9 \text { Io } \\ \text { Clearing } \\ 5 \text { IO }\end{array}\right\} \quad 7 \quad \ldots \quad 63$ $189246\left\{\begin{array}{c}\text { I } 43 \text { Larch at } 6 / 6 \\ \text { 100 Oak at } 4 / 4 \\ 8 \text { Spruce at } 3 / 2\end{array}\right\} \quad 76\left\{\begin{array}{c}\text { Felling } \\ 8 \text { IO } \\ \text { Clearing } \\ 4 \text { IO }\end{array}\right\} \quad 6 \quad \ldots \quad 57$ I90I $55\left\{\begin{array}{c}35 \text { Larch, } 735 \text { c. ft. } \\ 268 \text { Oak, } 4000,, \\ \text { IOSpruce,200 ," }\end{array}\right\} 240^{1} \quad 48 \quad 0^{1} \quad 22^{1} \quad \ldots \quad 170^{1}$

1 Items where estimate only was available. Such estimate must be . considered approximate only.

An account follows of some French forests near Valenciennes and Compiègne, the latter having been selected for this year's excursion of the Society. It is shown that the French coppicewith-standards of St. Amand, with a rotation of twenty-five years, produces a net annual revenue of $£ \mathrm{I} 2 s$. $8 d$. per acre, and that the splendid State forest of Retz, with an area of $32,55^{\circ}$ acres under beech and oak, produces a net annual revenue of I $7 s .7 d$. per acre, with a rotation of 150 years. Dr. Somerville, of the Board of Agriculture, the President of the English Arboricultural Society, contributes a notice on Prof. Schwappach's report on Prussian experiments with forest trees. The results most interesting to us are those obtained with Fraxinus americana, which withstands inundations better than Fraximus excelsior, and develops its foliage fourteen days later than the latter, thus escaping ordinary spring frosts. Larix leptolepis, the Japanese larch, is also said to resist insects and fungi better than the European larch, while it easily reproduces injured leaders.

A Forestry Society has just been started in Ireland, so that all parts of the British Isles are now enlisted in the cause.

W. R. FISHER.

\section{RECENT DISCOVERIES IN CHINESE TURKESTAN}

D) URING the last twelve years or so, the attention of scholars has been repeatedly arrested by remarkable discoveries of ancient Hindu manuscripts in Central Asia. In 1889 , Lieutenant Bower found an ancient birch-bark manuscript in Kuchār, in the northern portion of Chinese Turkestan. This "Bower Manuscript" was at once recognised as the oldest Indian manuscript extant. In I89I and I892, M. Petrovsky, Imperial ConsulGeneral of Russia at Kashgar, and the Rev. F. Weber, missionary in Leh, Ladakh, made no less important finds of old manuscripts in the region of Kashgar. Again, in 1897, the French traveller M. Dutreuil de Rhins found, in the vicinity of Khotan, some leaves of a very ancient birch-bark manuscript, in which M. Senart recognised fragments of a Prakrit version of the well-known Buddhist text, the Dhammapada. Meanwhile Dr. Hoernle, then principal of the Calcutta Madrasah, to whom we are indebted for a splendid edition of the "Bowe Manuscript," had drawn the attention of the Government of India to the remarkable records of ancient Hindu civilisation to be found in Central Asia, and on his recommendation inNO. I 707 , VOL. 66]
(I)

EXPenditure.

Annual recurrent Expenditure per acre:-

\begin{tabular}{|c|c|c|c|c|c|c|}
\hline Tithe Rent Che & $\ldots$ & $\cdots$ & $\cdots$ & ․ & $£ 0$ & 2 \\
\hline Land Tax ... & & $\ldots$ & $\ldots$ & .. & $\mathrm{o}$ & o \\
\hline Fencing and $\mathrm{D}$ & ing & $\ldots$ & $\ldots$ & $\ldots$ & o & I \\
\hline Rates $\quad \ldots$ & $\ldots$ & $\ldots$ & $\cdots$ & $\ldots$ & 0 & o \\
\hline Property Tax & $\ldots$ & $\ldots$ & ... & $\ldots$ & 0 & o \\
\hline Mole Catching & $\ldots$ & $\ldots$ & $\ldots$ & $\ldots$ & 0 & 0 \\
\hline Bailiff Wage & $\ldots$ & $\ldots$ & $\ldots$ & $\ldots$ & o & 2 \\
\hline & & & & & $£ 0$ & 7 \\
\hline
\end{tabular}

Moneys due at each Fell.

\begin{tabular}{|c|c|c|c|c|c|c|c|c|}
\hline Date. & & $\begin{array}{l}\text { and } 4 \text { per } \\
\text { Interest. } \\
f\end{array}$ & & $\begin{array}{l}\text { and } \\
\text { Inte } \\
\notin\end{array}$ & & $\begin{array}{l}\text { Total } \\
\text { due. } \\
£\end{array}$ & & $\begin{array}{l}\text { Balance } \\
\text { due. } \\
E\end{array}$ \\
\hline I $846-6$ I & $\ldots$ & 72 & $\cdots$ & 20 & $\ldots$ & 92 & $\ldots$ & 63 \\
\hline $1861-72$ & $\ldots$ & 97 & $\ldots$ & I 3 & $\ldots$ & I 10 & $\ldots$ & \\
\hline$\cdots$ & $\cdots$ & $\cdots$ & $\cdots$ & $\cdots$ & .. & .. & $\cdots$ & 97 \\
\hline $1872-80$ & .. & I I 8 & $\cdots$ & 9 & $\cdots$ & I 27 & $\cdots$ & \\
\hline$\cdots$ & $\cdots$ & $\cdots$ & $\cdots$ & $\cdots$ & $\cdots$ & $\cdots$ & $\cdots$ & 64 \\
\hline I $880-92$ & $\ldots$ & 102 & $\cdots$ & I 5 & $\cdots$ & I 7 & $\ldots$ & \\
\hline$\cdots$ & $\cdots$ & $\cdots$ & $\cdots$ & $\cdots$ & $\cdots$ & $\cdots$ & $\cdots$ & 00 \\
\hline $1892-1901$ & ... & 85 & $\cdots$ & 10 & $\ldots$ & 95 & $\ldots$ & \\
\hline
\end{tabular}

I90I Estimated Profit after paying balance due, $£ 75=£ 19$ per acre.

Planting Cost, £40; Rent, £I.

structions were issued to the British officials in Kashgar and Ladakh concerning the acquisition of antiquities from Chinese Turkestan, and a "British Collection of Central-Asian Antiquities" was gradually formed at Calcutta.

But all these had been more or less casual discoveries, and as soon as it became known that European officials were ready to pay high prices for such antiquities, native "treasure-seekers" made it their business to ransack the ancient sites in the desert, not without daniaging them, for manuscripts and other remains, and some of them were even unscrupulous enough to manufacture "old books" and sell them to Europeans as "antiques" unearthed in the desert. In these circumstances it became really a matter of urgency that systematic explorations, by some competent scholar, should at once be undertaken in these parts, all the more so as no part of Chinese Turkestan had ever been explored from an archæological point of view. No man could have been better fitted for this task than Dr. M. A. Stein, who, by his excellent topographical and archæological work in Kashmir and other parts of India, as well as by his scholarly edition and translation of the "Chronicles of the Kings of Kashmir," has shown that he combines the thoroughness and profound knowledge of the true scholar with the energy and hardiness, the practical experience and tact of the explorer. All students of India must feel thankful to the Indian Government for securing the services of such a man for the archæological and topographical exploration of Chinese Turkestan.

In June, I900, Dr. Stein was placed by the Government of India on a year's special duty, for the purpose of exploring the southern portion of Chinese Turkestan and more especially the region of Khotan. A Chinese passport from the Tsung-liYâmen was obtained, authorising him to travel and make excavations in Chinese territory. The Survey of India Depart. ment rendered material assistance by deputing one of the subsurveyors, Babu Ram Singh, to aceompany Dr. Stein on his travels, and by providing the necessary equipment of surveying instruments. Thus Dr. Stein was enabled, throughout the whole of his journey, to carry on geographical work along with his most interesting archæological researches.

A "Preliminary Report," after the completion of his journey, gives information about the character and scope of his explorations and their principal

1 "Preliminary Report on a Journey of Archrological and Topographical Exploration in Chinese Turkestan" By M. A. Stein, Indian Educational Service. Published under the authority of H.M.'s Secretary of State for India in Council. (London, igor.) 